\title{
Warming enhances carbon dioxide and methane fluxes from Red Sea seagrass (Halophila stipulacea) sediments
}

\author{
Celina Burkholz ${ }^{1,2}$, Neus Garcias-Bonet ${ }^{1, a}$, and Carlos M. Duarte ${ }^{1}$ \\ ${ }^{1}$ Red Sea Research Center (RSRC) and Computational Bioscience Research Center (CBRC), \\ King Abdullah University of Science and Technology (KAUST), Thuwal, Saudi Arabia \\ ${ }^{2}$ UWA Oceans Institute and School of Biological Sciences, The University of Western Australia, Crawley, WA, Australia \\ a current address: Global Change Research Group, IMEDEA (CSIC-UIB), Institut Mediterrani d'Estudis Avançats, \\ Esporles (Illes Balears), Spain
}

Correspondence: Carlos M. Duarte (carlos.duarte@kaust.edu.sa)

Received: 13 March 2019 - Discussion started: 15 April 2019

Revised: 24 November 2019 - Accepted: 2 March 2020 - Published: 3 April 2020

\begin{abstract}
Seagrass meadows are autotrophic ecosystems acting as carbon sinks, but they have also been shown to be sources of carbon dioxide $\left(\mathrm{CO}_{2}\right)$ and methane $\left(\mathrm{CH}_{4}\right)$. Seagrasses can be negatively affected by increasing seawater temperatures, but the effects of warming on $\mathrm{CO}_{2}$ and $\mathrm{CH}_{4}$ fluxes in seagrass meadows have not yet been reported. Here, we examine the effect of two disturbances on airseawater fluxes of $\mathrm{CO}_{2}$ and $\mathrm{CH}_{4}$ in Red Sea Halophila stipulacea communities compared to adjacent unvegetated sediments using cavity ring-down spectroscopy. We first characterized $\mathrm{CO}_{2}$ and $\mathrm{CH}_{4}$ fluxes in vegetated and adjacent unvegetated sediments, and then experimentally examined their response, along with that of the carbon (C) isotopic signature of $\mathrm{CO}_{2}$ and $\mathrm{CH}_{4}$, to gradual warming from $25^{\circ} \mathrm{C}$ (winter seawater temperature) to $37^{\circ} \mathrm{C}, 2^{\circ} \mathrm{C}$ above current maximum temperature. In addition, we assessed the response to prolonged darkness, thereby providing insights into the possible role of suppressing plant photosynthesis in supporting $\mathrm{CO}_{2}$ and $\mathrm{CH}_{4}$ fluxes. We detected 6-fold-higher $\mathrm{CO}_{2}$ fluxes in vegetated compared to bare sediments, as well as 10- to 100-fold-higher $\mathrm{CH}_{4}$ fluxes. Warming led to an increase in net $\mathrm{CO}_{2}$ and $\mathrm{CH}_{4}$ fluxes, reaching average fluxes of $10422.18 \pm 2570.12 \mu \mathrm{mol} \mathrm{CO}_{2} \mathrm{~m}^{-2} \mathrm{~d}^{-1}$ and $88.11 \pm 15.19 \mu \mathrm{mol} \mathrm{CH}_{4} \mathrm{~m}^{-2} \mathrm{~d}^{-1}$, while $\mathrm{CO}_{2}$ and $\mathrm{CH}_{4}$ fluxes decreased over time in sediments maintained at $25^{\circ} \mathrm{C}$. Prolonged darkness led to an increase in $\mathrm{CO}_{2}$ fluxes but a decrease in $\mathrm{CH}_{4}$ fluxes in vegetated sediments. These results add to previous research identifying Red Sea seagrass meadows as a significant source of $\mathrm{CH}_{4}$, while also indicating that
\end{abstract}

sublethal warming may lead to increased emissions of greenhouse gases from seagrass meadows, providing a feedback mechanism that may contribute to further enhancing global warming.

\section{Introduction}

Global warming, as a result of anthropogenic emissions of greenhouse gases, has led to ocean warming by $0.11^{\circ} \mathrm{C}$ between 1971 to 2010 (IPCC, 2014), with the global mean seasurface temperature predicted to increase further with additional emissions, depending on emission scenarios (IPCC, 2014). Ocean warming is leading to a shift in species and ecosystem processes (Hoegh-Guldberg and Bruno, 2010), including metabolic processes that are under strong thermal control (Brown et al., 2004; Garcias-Bonet et al., 2018, 2019b).

Ecosystem metabolism can also be a source of greenhouse gases, depending on the metabolic balance of the community, where autotrophic communities (net community production $(\mathrm{NCP})>0$ ) act as a sink for carbon dioxide $\left(\mathrm{CO}_{2}\right)$, while heterotrophic communities $(\mathrm{NCP}<0)$ act as a source of $\mathrm{CO}_{2}$ (Duarte et al., 2011). Since respiration rates tend to increase faster with warming than primary production does (Brown et al., 2004; Harris et al., 2006; Regaudie-De-Gioux and Duarte, 2012), warming may lead to the shifting of typically autotrophic ecosystems, such as seagrass meadows, to being net heterotrophic, thereby switching from acting as 
sinks to sources of $\mathrm{CO}_{2}$ (Harris et al., 2006). Emissions of metabolic greenhouse gases with ocean warming may provide a feedback mechanism by which anthropogenic emissions of greenhouse gases may lead to warming-dependent emissions by coastal ecosystems, therefore enhancing climate warming. This feedback effect is particularly likely to occur where methane $\left(\mathrm{CH}_{4}\right)$ is released, as $\mathrm{CH}_{4}$ is calculated to have a global warming potential 28 times larger than $\mathrm{CO}_{2}$ per mole of carbon (C) emitted (Myhre et al., 2013).

Indeed, $\mathrm{CO}_{2}$ and $\mathrm{CH}_{4}$ emissions from some tropical mangrove forests have been calculated and found to partially offset the capacity of mangroves to act as $\mathrm{C}$ sinks (Rosentreter et al., 2018). Whereas the emission of $\mathrm{CO}_{2}$ and $\mathrm{CH}_{4}$ from seagrass ecosystems has received far less attention, seagrass ecosystems have been reported to support $\mathrm{CH}_{4}$ emissions of the order of 1.4 to $401.3 \mu \mathrm{mol} \mathrm{CH}_{4} \mathrm{~m}^{-2} \mathrm{~d}^{-1}$ (cf. Table 1 in Garcias-Bonet and Duarte, 2017). Provided estimates of their global extent of seagrass meadows ranging from a documented $326000 \mathrm{~km}^{2}$ (Unsworth et al., 2019) to a predicted $1.6 \times 10^{6} \mathrm{~km}^{2}$ (Jayathilake and Costello, 2018), seagrass meadows may be important yet hitherto overlooked contributors to $\mathrm{CH}_{4}$ emissions. Garcias-Bonet and Duarte (2017) reported that seagrasses could contribute to global $\mathrm{CH}_{4}$ emissions by releasing $\mathrm{CH}_{4}$ at a rate of 0.09 to $2.7 \mathrm{Tg} \mathrm{yr}^{-1}$, which may increase the contribution of marine global emissions to previously reported global estimates by about $30 \%$ (GarciasBonet and Duarte, 2017).

Seagrasses are known to be autotrophic ecosystems, acting as C sinks (Duarte et al., 2010) supporting a global burial rate of $27.4 \mathrm{TgC} \mathrm{yr}^{-1}$ (Duarte et al., 2005b). They store carbon in their below- and aboveground biomass in the short term, as well as in their sediment in the long term (Duarte et al., 2005b). They account for $10 \%$ of the C storage in ocean sediments even though they only cover $0.2 \%$ of the ocean surface (Duarte et al., 2005b; Fourqurean et al., 2012). However, disturbances can lead to the loss of biomass and the emissions of stored $\mathrm{C}$ turning blue carbon ecosystems into C sources (Macreadie et al., 2015; Lovelock et al., 2017; Arias-Ortiz et al., 2018), which will ultimately contribute to global emissions intensifying the greenhouse effect. Lyimo et al. (2018) showed that stressors such as shading and grazing led to an increase of $\mathrm{CH}_{4}$ emissions by seagrass ecosystems by reducing their photosynthetic capacity. Garcias-Bonet and Duarte (2017) reported that $\mathrm{CH}_{4}$ release from seagrass sediments tended to increase with seawater temperature and suggested that $\mathrm{CH}_{4}$ emissions by seagrass ecosystems may be under temperature control in the Red Sea. Indeed, some seagrass ecosystems in the Red Sea have been shown to shift from an autotrophic to a heterotrophic state during the warmer summer months, indicating that some seagrass communities might already grow past their thermal optimum (Burkholz et al., 2019a).

The Red Sea ranks as the warmest sea in the world, with summer seawater temperatures reaching $35^{\circ} \mathrm{C}$, and is warming at higher rates $\left(0.17 \pm 0.07^{\circ} \mathrm{Cdecade}^{-1}\right.$; Chaidez et al.,
2017) than those of the global ocean $\left(0.11^{\circ} \mathrm{Cdecade}^{-1}\right.$; Rhein et al., 2013). Provided respiration rates and also $\mathrm{CH}_{4}$ fluxes in seagrass ecosystems are likely to increase with temperature, seagrass meadows in the Red Sea may be close to shifting from net sinks to net sources of greenhouse gases with further warming. Emission rates are also dependent on organic carbon supply, as high organic matter in sediments can promote an increase in $\mathrm{CH}_{4}$ production (Sotomayor et al., 1994; Gonsalves et al., 2011) and organic matter released from seagrass photosynthesis may also stimulate $\mathrm{CO}_{2}$ and $\mathrm{CH}_{4}$ production in the sediment community. Indeed, sediments in seagrass ecosystems support a 1.7 -fold increase in organic matter content compared to surrounding bare sediments, not only due to the slow turnover of biomass but also due to their ability to trap particles (Duarte et al., 2005a; Kennedy et al., 2010).

Here, we test the hypothesis that $\mathrm{CO}_{2}$ and $\mathrm{CH}_{4}$ fluxes by seagrass communities increase with warming. We do so by experimentally examining the effect of warming and plant activity on air-seawater fluxes of $\mathrm{CO}_{2}$ and $\mathrm{CH}_{4}$ in a Red Sea seagrass (Halophila stipulacea) community. The tropical seagrass species Halophila stipulacea (Forsskål) Ascherson is native to the Indian Ocean and is one of the most common species in the Red Sea (Qurban et al., 2019). It seems to be highly adaptive to various environments, as it is now found as an exotic species in the Mediterranean (Lipkin, 1975) and the Caribbean Sea (Ruiz and Ballantine, 2004), indicating its high resilience to changing conditions (Por, 1971). We first characterize air-seawater fluxes of $\mathrm{CO}_{2}$ and $\mathrm{CH}_{4}$ in Red Sea Halophila stipulacea communities compared to adjacent unvegetated sediments and then experimentally examine their response, along with that of the $\mathrm{C}$ isotopic signature of $\mathrm{CO}_{2}$ and $\mathrm{CH}_{4}$, to gradual warming from 25 to $37^{\circ} \mathrm{C}$. In addition, we assess the response to prolonged darkness, thereby providing insights into the possible role of plant photosynthesis in supporting $\mathrm{CO}_{2}$ and $\mathrm{CH}_{4}$ fluxes.

\section{Material and methods}

\subsection{Study site and sample collection}

Samples were collected at Al Kharar, a lagoon on the Saudi coast of the central Red Sea in February 2018. Two H. stipulacea meadows at a depth of 2-3 m, S1 $\left(22^{\circ} 56^{\prime} 46.5^{\prime \prime} \mathrm{N}\right.$, $\left.38^{\circ} 52^{\prime} 40.6^{\prime \prime} \mathrm{E}\right)$ and $\mathrm{S} 2\left(22^{\circ} 54^{\prime} 44.5^{\prime \prime} \mathrm{N}, 38^{\circ} 53^{\prime} 50.9^{\prime \prime} \mathrm{E}\right)$, were chosen to represent a range of organic matter content in the sediment and were selected to evaluate greenhouse gas fluxes. Moreover, the $H$. stipulacea meadow in the middle of the lagoon (S2) with higher biomass density (Table 1) was chosen as the study site to experimentally assess the role of temperature and darkness in greenhouse gas fluxes. The seagrass and sediment community was sampled using translucent cylindrical polyvinyl chloride (PVC) cores (26 cm length and $9.5 \mathrm{~cm}$ in diameter). The sharpened edge 
of the core was carefully pushed approximately $10 \mathrm{~cm}$ into the sediment with a rubber hammer so that the structure of leaves, roots and sediment stayed intact. A rubber stopper was then placed on top, before the core was carefully pulled out of the sediment without disturbing the structure and another rubber stopper was placed on the bottom of the core. The sediment cores were immediately transported to the laboratory.

\subsection{Sediment and plant characterization}

Once the cores were opened, the first $10 \mathrm{~cm}$ of the sediment and the plant biomass from the same cores were collected and dried at $60^{\circ} \mathrm{C}$ to a constant dry weight (DW). To characterize the two different $H$. stipulacea meadows, sediment and plant biomass samples were then ground to conduct sediment composition and nutrient analyses. A $50 \mathrm{~mL}$ tube was filled with sediment from the first $10 \mathrm{~cm}$, and the contents were dried at $60^{\circ} \mathrm{C}$ to a constant dry weight and weighed to determine the sediment bulk density $\left(\mathrm{g}\right.$ sediment $\mathrm{cm}^{-3}$ ). Organic matter content was analyzed by loss on ignition (LOI; Dean, 1974). Approximately $5 \mathrm{~g}$ of dried sediment was placed in a muffle furnace and burned at $450^{\circ} \mathrm{C}$ for $5 \mathrm{~h}$. The organic matter content was calculated as

$$
\begin{aligned}
& \% \mathrm{OM}= \\
& \frac{\text { pre-ignition weight }(\mathrm{g})-\text { post-ignition weight }(\mathrm{g})}{\text { pre-ignition weight }(\mathrm{g})} \times 100 .
\end{aligned}
$$

The carbonate content was estimated using a Pressure Gauge Calcimeter. Approximately $1 \mathrm{~g}$ of sample was placed in the calcimeter, and the recipient was filled with $10 \%$ hydrochloric acid $(\mathrm{HCl})$. The mass of $\mathrm{CaCO}_{3}$ in the sample $(\mathrm{g})$ was then calculated as follows:

$m_{\mathrm{CaCO}_{3}}=\frac{p-b}{a \times w}$,

where $p$ is the pressure recorded (ppm), $b$ is the slope and $a$ the intercept derived from the calibration curve, and $w$ is the exact weight of each sediment sample $(\mathrm{g})$. The percentage of $\mathrm{CaCO}_{3}$ in the sample (\% DW) was then calculated using Eq. (3):

$\%_{\mathrm{CaCO}_{3}}=\frac{m_{\mathrm{CaCO}_{3}}}{w \times 100}$.

Dried sediment and plant samples were digested using US Environmental Protection Agency (EPA) method 3052 and analyzed with nitric acid $\left(\mathrm{HNO}_{3}\right)$ and $\mathrm{HCl}$ using US EPA method 200.7 following manufacturer instructions. The phosphorus content (\% DW) was analyzed using inductively coupled plasma optical emission spectroscopy (ICP-OES) on an Agilent 5110 ICP-OES (Agilent Technologies, Santa Clara, CA, USA). The $\mathrm{C}$ and nitrogen $(\mathrm{N})$ concentration of both plants and sediments was analyzed after acidification with $\mathrm{HCl}$ (Hedges and Stern, 1984), using a FLASH 2000 Organic Elemental Analyzer (CHNS/O-2, Thermo Fisher
Scientific, Waltham, MA, USA). The isotopic signature of ${ }^{13} \mathrm{C}$ in sediment organic matter was analyzed, using cavity ring-down spectroscopy (CRDS G2201-I, Picarro Inc., Santa Clara, CA, USA), from the ${ }^{13} \mathrm{C}$ of $\mathrm{CO}_{2}$ released by a combustion module (Costech Analytical Technologies Inc., CA, USA) delivering the $\mathrm{CO}_{2}$ resulting from combusting the sediment organic matter to the CRDS instrument.

\subsection{Assessment of carbon dioxide and methane air-seawater fluxes}

In February 2018, triplicate cores from vegetated and adjacent bare (about $5 \mathrm{~m}$ from the edge of the seagrass patch) sediments were collected from sites S1 and S2 and transferred to incubation chambers (Percival Scientific Inc., Perry, IA, USA) set at $25^{\circ} \mathrm{C}$ with a $12 \mathrm{~h}$ light (up to $70 \mu$ mol photons $\left.\mathrm{m}^{-2} \mathrm{~s}^{-1}\right): 12 \mathrm{~h}$ dark $(12 \mathrm{~h} \mathrm{~L}: 12 \mathrm{hD})$ cycle to measure the greenhouse gas $\left(\mathrm{CO}_{2}\right.$ and $\left.\mathrm{CH}_{4}\right)$ fluxes supported by these communities. Before measuring fluxes, the water overlying the sediment inside the cores was carefully siphoned until only $5 \mathrm{~mm}$ of water remained over the sediment surface; fresh seawater was carefully siphoned in the core to avoid disturbing the redoxcline, leaving a headspace of approximately $5-6 \mathrm{~cm}$; and the cores were closed again with stoppers containing gas-tight valves. The cores were left for $1 \mathrm{~h}$ to allow for equilibration between the seawater and the headspace air. We then sampled $10 \mathrm{~mL}$ of air from each core using a syringe and injected the air sample in a cavity ring-down spectrometer (Picarro Inc., Santa Clara, CA, USA) through a Small Sample Isotopic Module extension (SSIM A0314, Picarro Inc., Santa Clara, CA, USA), which provided both the partial pressure and the isotopic carbon composition of the $\mathrm{CO}_{2}$ and $\mathrm{CH}_{4}$ in the air sample. One sample from each core was taken at the start $\left(T_{0}\right)$, after $12 \mathrm{~h}$ of light $\left(T_{1}\right)$ and after $12 \mathrm{~h}$ of dark $\left(T_{2}\right)$. The daily $\mathrm{CO}_{2}$ and $\mathrm{CH}_{4}$ fluxes were calculated from the difference between $T_{0}$ and $T_{2}$ taking into account the core surface area $\left(\mu \mathrm{mol} \mathrm{m}{ }^{-2} \mathrm{~d}^{-1}\right)$. Before and after each sampling, two standards were measured (A: 750 ppm $\mathrm{CO}_{2}, 9.7 \mathrm{ppm} \mathrm{CH} \mathrm{CH}_{4}$; $\mathrm{B}: 250.5 \mathrm{ppm} \mathrm{CO}_{2}$, $\left.3.25 \mathrm{ppm} \mathrm{CH}_{4}\right)$.

\subsection{Effect of warming on carbon dioxide and methane air-seawater fluxes}

In March 2018, we collected 18 vegetated and 18 bare sediment cores from site S2 to evaluate the response of greenhouse gas fluxes to warming. The sampling was performed as described above. The cores were transferred to the Coastal and Marine Resources Core Lab (CMOR, KAUST, Saudi Arabia). Nine vegetated and nine bare sediment cores each were placed in two aquaria with flow-through seawater set at in situ temperature $\left(25^{\circ} \mathrm{C}\right)$ and with a $12 \mathrm{hL}$ (up to $200 \mu \mathrm{mol}$ photons $\mathrm{m}^{-2} \mathrm{~s}^{-1}$ ) : $12 \mathrm{~h} \mathrm{D}$ cycle. One aquarium was maintained at $25^{\circ} \mathrm{C}$ over the entire duration of the experiment to serve as a control for temperature-independent 
Table 1. Summary of vegetated sediment, bare sediment and seagrass leaves characteristics in the study sites (S1 and S2). NA: not available.

\begin{tabular}{|c|c|c|c|c|c|c|}
\hline & \multicolumn{3}{|c|}{ S1 } & \multicolumn{3}{|c|}{$\mathrm{S} 2$} \\
\hline & $\begin{array}{l}\text { Vegetated } \\
\text { sediment }\end{array}$ & $\begin{array}{r}\text { Bare } \\
\text { sediment }\end{array}$ & $\begin{array}{r}\text { Seagrass } \\
\text { leaf }\end{array}$ & $\begin{array}{l}\text { Vegetated } \\
\text { sediment }\end{array}$ & $\begin{array}{r}\text { Bare } \\
\text { sediment }\end{array}$ & $\begin{array}{r}\text { Seagrass } \\
\text { leaf }\end{array}$ \\
\hline $\mathrm{C}$ concentration $(\% \mathrm{DW})$ & $0.43 \pm 0.05$ & $0.41 \pm 0.03$ & $17.6 \pm 2.72$ & $0.55 \pm 0.03$ & $0.52 \pm 0.02$ & $15.32 \pm 1.48$ \\
\hline $\mathrm{N}$ concentration $(\% \mathrm{DW})$ & $0.07 \pm 0.01$ & $0.12 \pm 0.01$ & $1.06 \pm 0.17$ & $0.08 \pm 0.002$ & $0.09 \pm 0.01$ & $0.94 \pm 0.07$ \\
\hline $\mathrm{P}$ concentration $(\% \mathrm{DW})$ & $0.03 \pm 0.001$ & $0.03 \pm 0$ & $0.12 \pm 0.01$ & $0.02 \pm 0$ & $0.02 \pm 0.001$ & $0.11 \pm 0.01$ \\
\hline Carbonate content (\% DW) & $91.75 \pm 0.56$ & $91.65 \pm 0$ & NA & $82.61 \pm 0.50$ & $83.63 \pm 0$ & NA \\
\hline Organic matter (\% DW) & $2.45 \pm 0.09$ & $2.46 \pm 0.16$ & NA & $3.26 \pm 0.03$ & $2.95 \pm 0.04$ & NA \\
\hline Bulk density $\left(\mathrm{g} \mathrm{cm}^{-3}\right)$ & $1.15 \pm 0.02$ & $1.28 \pm 0.03$ & NA & $1.1 \pm 0.07$ & $1.2 \pm 0.04$ & NA \\
\hline Seagrass biomass $\left(\mathrm{g} \mathrm{DW} \mathrm{m}^{-2}\right.$ ) & $60.87 \pm 1.24$ & NA & NA & $164.66 \pm 20.54$ & NA & NA \\
\hline Sediment $\delta^{13} \mathrm{C}-\mathrm{C}_{\mathrm{org}}(\% o)$ & $-15.77 \pm 0.07$ & $-15.94 \pm 0.1$ & NA & $-15.81 \pm 0.13$ & $-16.36 \pm 0.28$ & NA \\
\hline $\begin{array}{l}\text { Seagrass leaf } \delta^{13} \mathrm{C}-\mathrm{C}(\%) \\
\text { extracted from Duarte et al. (2018) }\end{array}$ & & & & $=0.27$ & & \\
\hline
\end{tabular}

variability in fluxes. The temperature in the second aquarium was increased at a rate of $1^{\circ} \mathrm{Cd}^{-1}$ to allow for acclimatization of the vegetated and bare cores. $\mathrm{CO}_{2}$ and $\mathrm{CH}_{4}$ fluxes were measured at every $2{ }^{\circ} \mathrm{C}$ from 25 to $37^{\circ} \mathrm{C}$, with parallel measurements conducted on the cores maintained at $25^{\circ} \mathrm{C}$. After a $1 \mathrm{~d}$ acclimation period at each new temperature, the cores were closed with the stoppers and transferred to incubation chambers (Percival Scientific Inc., Perry, IA, USA) set at the target temperature for $\mathrm{CO}_{2}$ and $\mathrm{CH}_{4}$ flux measurements as described above. After the $24 \mathrm{~h}$ measurements, the cores were returned to the aquaria. An additional core kept at each of the constant temperature and warming sets was sampled every $4 \mathrm{~d}$ (i.e., at $4{ }^{\circ} \mathrm{C}$ temperature intervals in the warming treatment) to analyze sediment composition. The cores used for flux estimates were opened after the final measurement ( $20 \mathrm{~d}$ since collection) to estimate the plant biomass and analyze the sediment composition at the end of the experiment.

\subsection{Effect of darkness on carbon dioxide and methane air-seawater fluxes}

In May 2018, six vegetated and six bare sediment cores were collected from site $\mathrm{S} 2$ and kept at a constant $25^{\circ} \mathrm{C}$ with a $24 \mathrm{~h}$ dark cycle. Only during the measurements in the incubators were the cores exposed to a $12 \mathrm{hL}: 12 \mathrm{hD}$ cycle, allowing fluxes to be compared with those measured in cores permanently maintained with the $12 \mathrm{hL}: 12 \mathrm{~h} \mathrm{D}$ photoperiod. $\mathrm{CO}_{2}$ and $\mathrm{CH}_{4}$ fluxes were measured after the first day of acclimation and then kept in the aquaria until signs of seagrass mortality started to become apparent, which occurred after 1 week in the dark. $\mathrm{CO}_{2}$ and $\mathrm{CH}_{4}$ fluxes were measured at alternate days as detailed above. At the end of the experiment ( $21 \mathrm{~d}$ since collection), the cores were opened and sampled to assess plant biomass and sediment composition.

\subsection{Measurements of carbon dioxide and methane air-seawater fluxes}

The concentration of $\mathrm{CO}_{2}$ in the seawater after equilibrium was calculated based on the concentration of $\mathrm{CO}_{2}$ in the headspace (ppm) measured by CRDS according to Sea et al. (2018) and Wilson et al. (2012):

$\left[\mathrm{CO}_{2}\right]_{\mathrm{w}}=10^{-6} \beta m_{\mathrm{a}} p_{\text {dry }}$,

where $\beta$ is the Bunsen solubility coefficient of $\mathrm{CO}_{2}$ $\left(\mathrm{mol} \mathrm{mL} \mathrm{L}^{-1} \mathrm{~atm}^{-1}\right), m_{\mathrm{a}}$ is the $\mathrm{CO}_{2}$ concentration measured in the headspace (ppm) and $p_{\text {dry }}$ is the atmospheric pressure of dry air (atm). The Bunsen solubility coefficient of $\mathrm{CO}_{2}$ was calculated using Eq. (5):

$\beta=H^{\mathrm{cp}} \times(\mathrm{RT})$,

where $H^{\mathrm{cp}}$ is the Henry constant $\left(\mathrm{mol} \mathrm{mL}^{-1} \mathrm{~atm}^{-1}\right)$ calculated using the marelac $\mathrm{R}$ package (Soetaert et al., 2016). $R$ is the ideal gas constant $\left(0.082057459 \mathrm{~atm} \mathrm{~L} \mathrm{~mol} \mathrm{~mL}{ }^{-1} \mathrm{~K}^{-1}\right)$, and $T$ is the standard temperature $(273.15 \mathrm{~K})$.

The atmospheric pressure of dry air $\left(p_{\text {dry }}\right)$ was calculated as follows:

$p_{\text {dry }}=p_{\text {wet }}\left(1-\% \mathrm{H}_{2} \mathrm{O}\right)$,

where $p_{\text {wet }}$ is the atmospheric pressure of wet air. Boyle's law was applied as gas was collected several times from the same core.

The concentration of dissolved $\mathrm{CO}_{2}$ in seawater before equilibrium was then calculated using Eq. (7):

$\left[\mathrm{CO}_{2}\right]_{\mathrm{aq}}=\frac{\left[\mathrm{CO}_{2}\right]_{\mathrm{w}} V_{\mathrm{w}}+10^{-6} m_{\mathrm{a}} V_{\mathrm{a}}}{V_{\mathrm{w}}}$,

where $V_{\mathrm{W}}$ is the volume of seawater $(\mathrm{mL})$ and $V_{\mathrm{a}}$ is the volume of the headspace $(\mathrm{mL})$. The units were then converted to nanomolar (nM):

$$
\left[\mathrm{CO}_{2}\right]_{\mathrm{aq}}=\frac{10^{9} \times p_{\mathrm{dry}}\left[\mathrm{CO}_{2}\right]_{\mathrm{aq}}}{\mathrm{RT}} \text {. }
$$


The daily $\mathrm{CO}_{2}$ fluxes were calculated from the difference between $T_{0}$ and $T_{2}$ taking into account the core surface area $\left(\mu \mathrm{mol} \mathrm{m}{ }^{-2} \mathrm{~d}^{-1}\right)$.

Daily $\mathrm{CH}_{4}$ fluxes were estimated using the same calculations as for the $\mathrm{CO}_{2}$ fluxes with the exception of the Bunsen solubility coefficient. The Bunsen solubility coefficient was calculated as a function of the seawater temperature and salinity following Wiesenburg and Guinasso (1979). The total $\mathrm{CO}_{2}$ greenhouse-equivalent fluxes were calculated assuming $\mathrm{CH}_{4}$ to have a greenhouse potential 28 -fold greater than that of $\mathrm{CO}_{2}$ per mol of $\mathrm{C}$ (Myhre et al., 2013).

\subsection{Isotopic composition of carbon dioxide $\left(\delta^{13} \mathrm{C}-\mathrm{CO}_{2}\right)$ and methane $\left(\delta^{13} \mathrm{C}-\mathrm{CH}_{4}\right)$}

The isotopic signature of $\mathrm{CO}_{2}$ and $\mathrm{CH}_{4}$ produced during the incubations was estimated using Keeling plots following Garcias-Bonet and Duarte (2017). $\delta^{13} \mathrm{C}_{\text {of }} \mathrm{CO}_{2}$ and $\mathrm{CH}_{4}$ produced in our incubations was extracted from the intercept of the linear regression between the inverse of the gas concentration $\left(\mathrm{ppm}^{-1}\right)$ and the isotopic signature measured from the discrete samples in the CDRS instrument.

\subsection{Data analysis}

The data were analyzed for normality using the ShapiroWilk test. The Mann-Whitney test and Student's $t$ test were used to test for differences in seagrass and sediment composition between sites and between vegetated and bare sediments, and analysis of variation (ANOVA) and the KruskalWallis test were used to test for differences between vegetated and bare sediments and both sites. To assess differences in greenhouse gas fluxes between different $\mathrm{H}$. stipulacea communities, differences in $\mathrm{CO}_{2}$ and $\mathrm{CH}_{4}$ fluxes were analyzed between sites and between vegetated and bare sediment by using the Kruskal-Wallis test. Trends in the flux between the communities experiencing warming and the ones maintained at $25^{\circ} \mathrm{C}$, as well as in the isotopic signature of $\delta^{13} \mathrm{C}-\mathrm{CO}_{2}$ and $\delta^{13} \mathrm{C}-\mathrm{CH}_{4}$ over time, were analyzed by linear regression. When assessing the effect of darkness on greenhouse gas fluxes, the trend of $\mathrm{CO}_{2}$ and $\mathrm{CH}_{4}$ fluxes and their isotopic signatures were analyzed by linear regression. The statistical analyses were conducted in PRISM 5 (GraphPad Software, La Jolla, CA, USA) and JMP Pro 13.1.0 (SAS Institute Inc., Cary, NC, USA). The data are openly available from Burkholz et al. (2019b).

\section{Results}

\subsection{Seagrass and sediment composition}

Carbon, nitrogen and phosphorus $(\mathrm{P})$ concentrations in seagrass leaves were low, but they were 4- to 40-fold higher than vegetated and bare sediment concentrations (Table 1). Seagrass sampled in site $\mathrm{S} 1$ had the highest $\mathrm{C}, \mathrm{N}$ and $\mathrm{P}$ concen- trations in the leaves, while sediment $\mathrm{C}$ and $\mathrm{P}$ concentrations differed significantly between sites (ANOVA, $p<0.05$, and Kruskal-Wallis, $p<0.001$, respectively), with the highest $\mathrm{C}$ and the lowest $\mathrm{P}$ concentrations found in the sediment of $\mathrm{S} 2$ (Table 1). There were no consistent differences in $\mathrm{C}, \mathrm{N}$ and $\mathrm{P}$ concentration in bare and vegetated sediments (Table 1).

The sediments had high, but variable, carbonate concentrations, which differed between sites (Kruskal-Wallis, $p<$ 0.0001 ; Table 1). The organic matter content was slightly increased in $\mathrm{S} 2$ compared to $\mathrm{S} 1$, in both vegetated ( $t$ test, $p<0.0001)$ and bare $(t$ test, $p<0.001)$ sediments (Table 1). Sediment bulk density was similar in both $\mathrm{S} 1$ and $\mathrm{S} 2$ sites, but vegetated sediments in $\mathrm{S} 1$ showed significantly lower bulk density compared to bare sediments ( $t$ test, $p<$ 0.05 ; Table 1). Seagrass biomass density was significantly higher in $\mathrm{S} 2$ compared to $\mathrm{S} 1$ ( $t$ test, $p<0.05$ ). The isotopic signature of sediment organic carbon ranged across sites from $-15.77 \pm 0.07 \%$, in vegetated sediments, to $-16.36 \pm$ $0.28 \%$, in bare sediments (Table 1 ). The carbon isotopic signature of seagrass leaves from the same location has been recently reported as $-7.96 \pm 0.27 \%$ ob Duarte et al. (2018).

\subsection{Carbon dioxide and methane air-seawater fluxes}

The daily $\mathrm{CO}_{2}$ flux was up to 6-fold higher in vegetated compared to bare sediments and tended to be generally higher in $\mathrm{S} 2$ compared to $\mathrm{S} 1$, where bare sediments showed net $\mathrm{CO}_{2}$ uptake, although differences were not significant (KruskalWallis, $p>0.05$; Fig. 1a). At both sites, S1 and S2, the daily net $\mathrm{CH}_{4}$ flux was 10 - to 100 -fold higher in vegetated compared to adjacent bare sediments with generally higher fluxes at S2 (Kruskal-Wallis, $p<0.01$; Fig. 1b). The total $\mathrm{CO}_{2}$ equivalent $\left(\mathrm{CO}_{2}\right.$-eq) fluxes varied between sites and were higher in the vegetated compared to the bare sediments (Kruskal-Wallis, $p<0.01$; Fig. 1c).

\subsection{Effect of warming on carbon dioxide and methane air-seawater fluxes}

The $\mathrm{CO}_{2}$ fluxes in vegetated sediments increased greatly with warming $\left(R^{2}=0.38, p<0.001\right)$ but decreased over time when the community was maintained at $25^{\circ} \mathrm{C}\left(R^{2}=0.30\right.$, $p<0.01$; Fig. 2a, Table $\mathrm{S} 1$ in the Supplement), shifting from sediments showing net $\mathrm{CO}_{2}$ emission to net $\mathrm{CO}_{2}$ uptake. Similar responses were observed in the bare sediments, where $\mathrm{CO}_{2}$ fluxes increased with warming $\left(R^{2}=0.54, p<\right.$ 0.0001 ), while the community tended to shift over time from supporting net $\mathrm{CO}_{2}$ emission to net $\mathrm{CO}_{2}$ uptake when maintained at $25^{\circ} \mathrm{C}$ (Fig. 2b). The net $\mathrm{CO}_{2}$ flux - i.e., the difference between the $\mathrm{CO}_{2}$ fluxes in warming sediments and those at sediments maintained at $25^{\circ} \mathrm{C}$ - increased significantly with warming in both the vegetated and the bare sediment $\left(R^{2}=0.74\right.$ and $p<0.05$, and $R^{2}=0.91$ and $p<0.001$, respectively; Fig. 2c). 

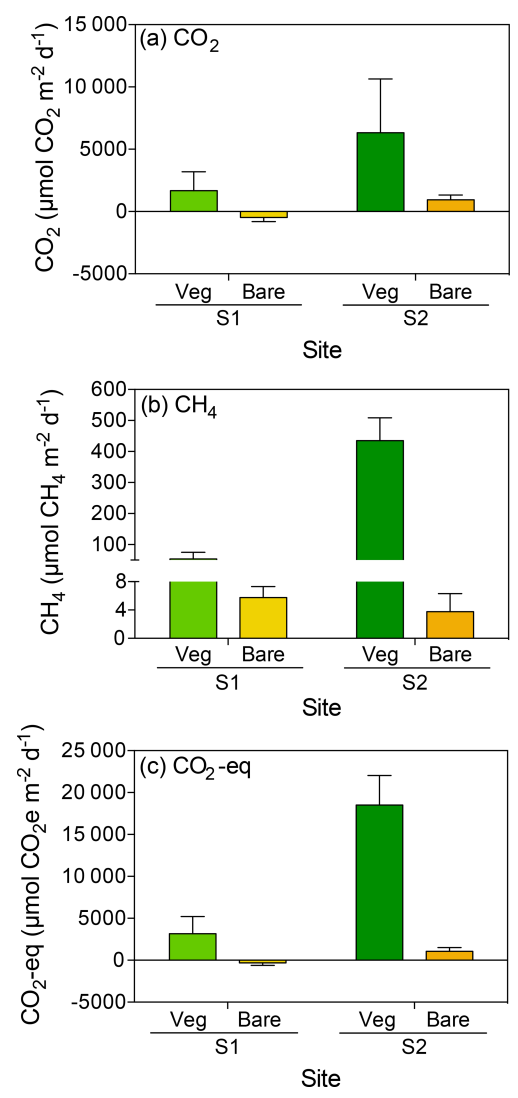

Figure 1. Mean $+\mathrm{SE}$ (a) $\mathrm{CO}_{2}$, (b) $\mathrm{CH}_{4}$ and (c) $\mathrm{CO}_{2}$-eq fluxes in vegetated (green) and adjacent bare (yellow) sediments at two sites (S1 and S2) in the central Red Sea.

$\mathrm{CH}_{4}$ fluxes declined over time when the sediments were maintained at $25^{\circ} \mathrm{C}$, both in vegetated $\left(R^{2}=0.43, p<\right.$ 0.001 ; Fig. 2d) and, less strongly, bare sediments $\left(R^{2}=0.24\right.$, $p<0.01$; Fig. 2e, Table S2). In contrast, $\mathrm{CH}_{4}$ fluxes tended to increase with temperature in vegetated (Fig. 2d) and bare (Fig. 2e) sediments gradually warmed from 25 to $37^{\circ} \mathrm{C}$, although it was not significant ( $p>0.05$ and $p>0.05$, respectively; Table S2). The net $\mathrm{CH}_{4}$ fluxes - i.e., the difference between the $\mathrm{CH}_{4}$ fluxes in sediments exposed to warming and sediments maintained at $25^{\circ} \mathrm{C}$ - increased significantly over time (i.e., with warming) in vegetated $\left(R^{2}=0.69, p<0.05\right)$ but not in bare sediments ( $p>0.05$; Fig. $2 \mathrm{f}$ ). An outlier in the vegetated sediment at $33{ }^{\circ} \mathrm{C}$ supporting extreme emissions $\left(\mathrm{CO}_{2}\right.$ flux of $55170 \mu \mathrm{mol} \mathrm{CO} \mathrm{m}^{-2} \mathrm{~d}^{-1}$ and $\mathrm{CH}_{4}$ flux of $699.8 \mathrm{CH}_{4} \mu \mathrm{mol} \mathrm{m}{ }^{-2} \mathrm{~d}^{-1}$ ) was observed on day 14 in one of the replicates of the warming treatment where seagrass had died (Fig. 2a and d); it was excluded from the regression analyses reported above.

Despite $\mathrm{CO}_{2}$ and $\mathrm{CH}_{4}$ fluxes showing the same response to warming in both types of sediment, vegetated sediments held higher fluxes than bare sediments. The relationship between net $\mathrm{CO}_{2}$ and $\mathrm{CH}_{4}$ fluxes in bare vs. vegetated sediments showed that both bare and vegetated communities tended to act as net $\mathrm{CO}_{2}$ sinks at $25^{\circ} \mathrm{C}$, but tended to act as $\mathrm{CO}_{2}$ sources at warmer temperatures (Fig. 3a), whereas net $\mathrm{CH}_{4}$ fluxes were 3- to 8-fold higher in vegetated compared to bare sediments (Fig. 3b). The $\mathrm{CH}_{4} / \mathrm{CO}_{2}$ ratio declined in the vegetated sediments exposed to warming from 7 to $0.8 \%$. For $\mathrm{CO}_{2}$ and $\mathrm{CH}_{4}$ fluxes in vegetated sediments, the $Q_{10}$ value for the temperature range $25-37^{\circ} \mathrm{C}$ was 9 and 1.5 , respectively, while the $Q_{10}$ value for bare sediments was 13.8 and 4.2 , respectively.

\subsection{Effect of darkness on carbon dioxide and methane air-seawater fluxes}

The vegetated sediment shifted over time from showing net $\mathrm{CO}_{2}$ uptake to net $\mathrm{CO}_{2}$ emission when maintained in the dark $\left(R^{2}=0.70, p<0.05\right)$, while the increase in the bare sediment was not significant ( $p>0.05$; Fig. 4a, Table S3). In contrast, when vegetated sediment was maintained at $25^{\circ} \mathrm{C}$ with a $12 \mathrm{hL}: 12 \mathrm{hD}$ photoperiod, the community shifted from net $\mathrm{CO}_{2}$ emission to net $\mathrm{CO}_{2}$ uptake (Mann-Whitney, $p<0.05$; Fig. 5a). In bare sediments, $\mathrm{CO}_{2}$ fluxes showed the same trend in cores maintained at $25^{\circ} \mathrm{C}$ with a $12 \mathrm{~h} \mathrm{~L}: 12 \mathrm{~h} \mathrm{D}$ photoperiod as under dark conditions (Fig. 5b).

When vegetated sediments were kept in the dark, net $\mathrm{CH}_{4}$ fluxes decreased 5-fold over time $\left(R^{2}=0.99, p<0.0001\right.$; Fig. 4b, Table S4). However, the $\mathrm{CH}_{4}$ fluxes did not differ significantly between vegetated cores maintained at $25^{\circ} \mathrm{C}$ in the $12 \mathrm{hL}: 12 \mathrm{hD}$ photoperiod or in the dark (MannWhitney, $p>0.05)$, showing the same trend of decreasing $\mathrm{CH}_{4}$ fluxes (Fig. 5c). In the bare sediment, $\mathrm{CH}_{4}$ fluxes in sediments kept in the dark were higher than those at $25^{\circ} \mathrm{C}$ with a $12 \mathrm{~h} \mathrm{~L}: 12 \mathrm{~h}$ D photoperiod, with significant differences only observed on days 14 and 20 (Mann-Whitney, $p<0.05$ and $p<0.05$, respectively; Fig. 5d).

\subsection{Isotopic composition of carbon dioxide $\left(\delta^{13} \mathrm{C}-\mathrm{CO}_{2}\right)$ and methane $\left(\delta^{13} \mathrm{C}-\mathrm{CH}_{4}\right)$}

The isotopic signature of the $\delta^{13} \mathrm{C}-\mathrm{CO}_{2}$ became heavier with warming in the bare sediment, increasing from $-22.36 \pm$ $-4.97 \% \circ \delta^{13} \mathrm{C}$ at $25^{\circ} \mathrm{C}$ to $-9.01 \pm 0.98 \%$ o $\delta^{13} \mathrm{C}$ at $37^{\circ} \mathrm{C}$ $\left(R^{2}=0.91, p<0.001\right)$, while the other treatments showed similar values over time, ranging from a minimum average of $-17.89 \pm 1.81 \%$ o to a maximum average of $-11.55 \pm 5.32 \%$ o $\delta^{13} \mathrm{C}$ (Fig. 6a-d).

The isotopic signature of $\delta^{13} \mathrm{C}-\mathrm{CH}_{4}$ decreased over time in both vegetated and bare sediments, whether they were maintained at constant temperature or experienced warming (Fig. 6e-h). The isotopic signature in the vegetated sediment exposed to warming decreased significantly from $-50.8 \%$ o to $-54.06 \%$ o $\left(R^{2}=0.67, p<0.001\right)$.

The $\delta^{13} \mathrm{C}$ isotopic composition of both $\mathrm{CO}_{2}$ and $\mathrm{CH}_{4}$ became heavier over time when the community was kept in the dark (Fig. 7), with a significant increase of $\delta^{13} \mathrm{C}-\mathrm{CH}_{4}$ in bare sediments $\left(R^{2}=0.94, p<0.01\right.$; Fig. $\left.7 \mathrm{~d}\right)$. 

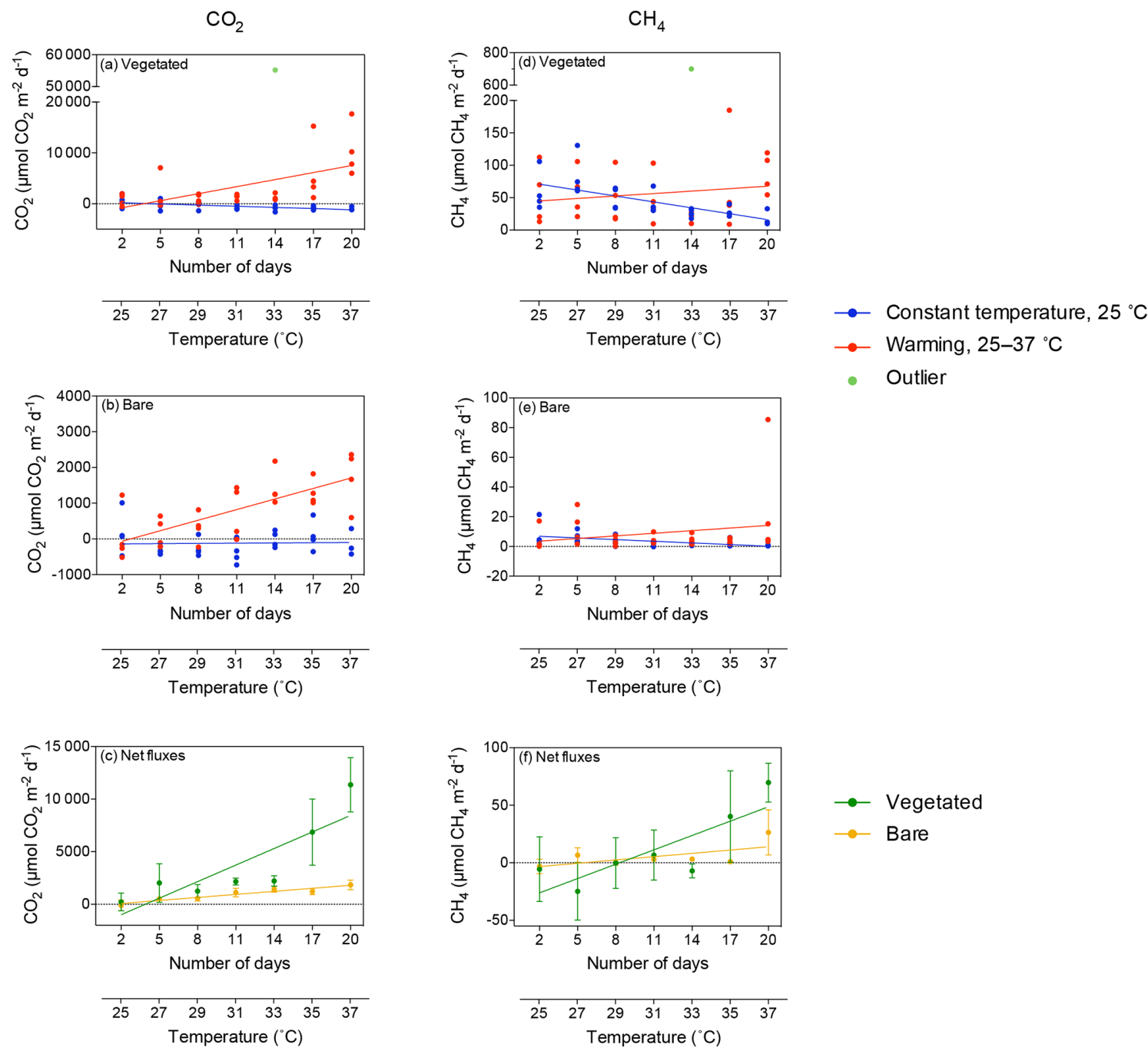

Figure 2. Mean $\pm \mathrm{SE} \mathrm{CO}_{2}$ (left) and $\mathrm{CH}_{4}$ (right) fluxes in (a, d) vegetated and (b, e) bare sediments. Symbols indicate each replicate of the community experiencing warming from 25 to $37^{\circ} \mathrm{C}$ (red) and the community maintained at $25^{\circ} \mathrm{C}$ (blue) over the experimental period (number of days since the onset of the experiment). An outlier at $33^{\circ} \mathrm{C}$ in vegetated sediments in shown in green. (c, f) $\mathrm{Mean} \pm \mathrm{SE}(\mathbf{c}) \mathrm{CO}_{2}$ and (f) $\mathrm{CH}_{4}$ net fluxes in vegetated (green) and bare (yellow) sediments over the experimental period (number of days since the onset of the experiment). The second $x$ axis indicates the experimental temperature for the community exposed to warming from 25 to $37^{\circ} \mathrm{C}$. Lines represent a fitted linear equation.
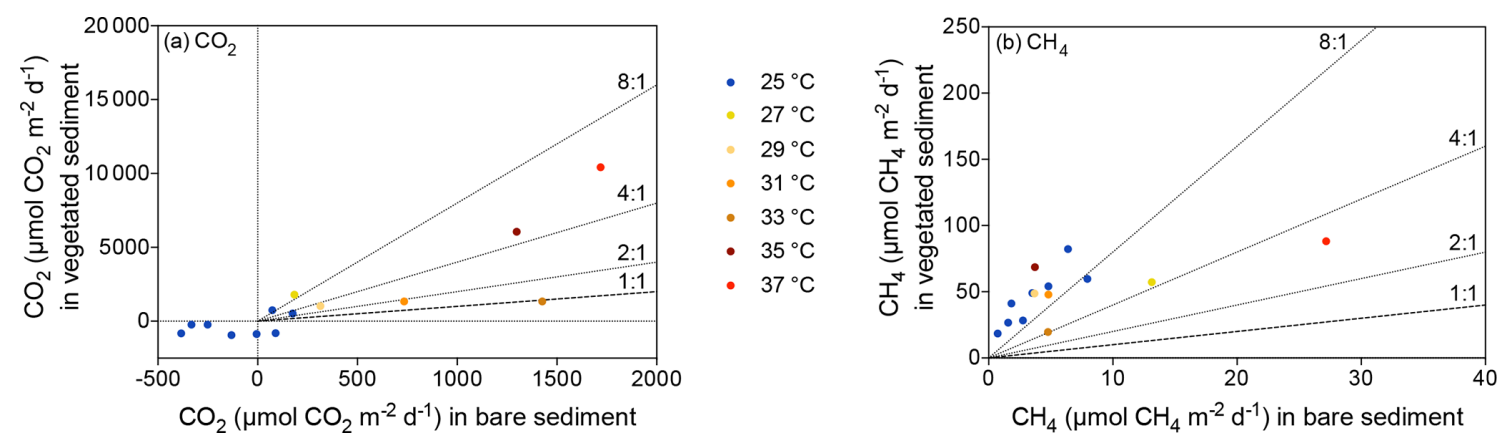

Figure 3. Relationship between vegetated and bare sediments for (a) $\mathrm{CO}_{2}$ and (b) $\mathrm{CH}_{4}$ fluxes. Symbols indicate different temperatures ranging from 25 to $37^{\circ} \mathrm{C}$; the dashed line indicates $1: 1$; and dotted lines show $2: 1,4: 1$ and $8: 1$. 

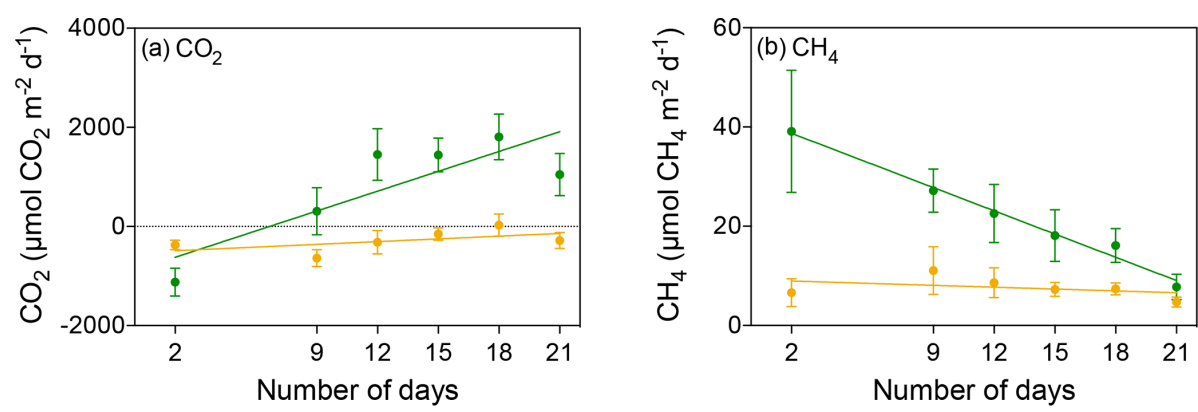

$\rightarrow$ Vegetated $\rightarrow$ Bare

Figure 4. Mean $\pm \mathrm{SE}$ (a) $\mathrm{CO}_{2}$ and (b) $\mathrm{CH}_{4}$ fluxes in vegetated (green) and bare (yellow) sediments of communities exposed to prolonged darkness over the experimental period (number of days since the onset of the experiment).
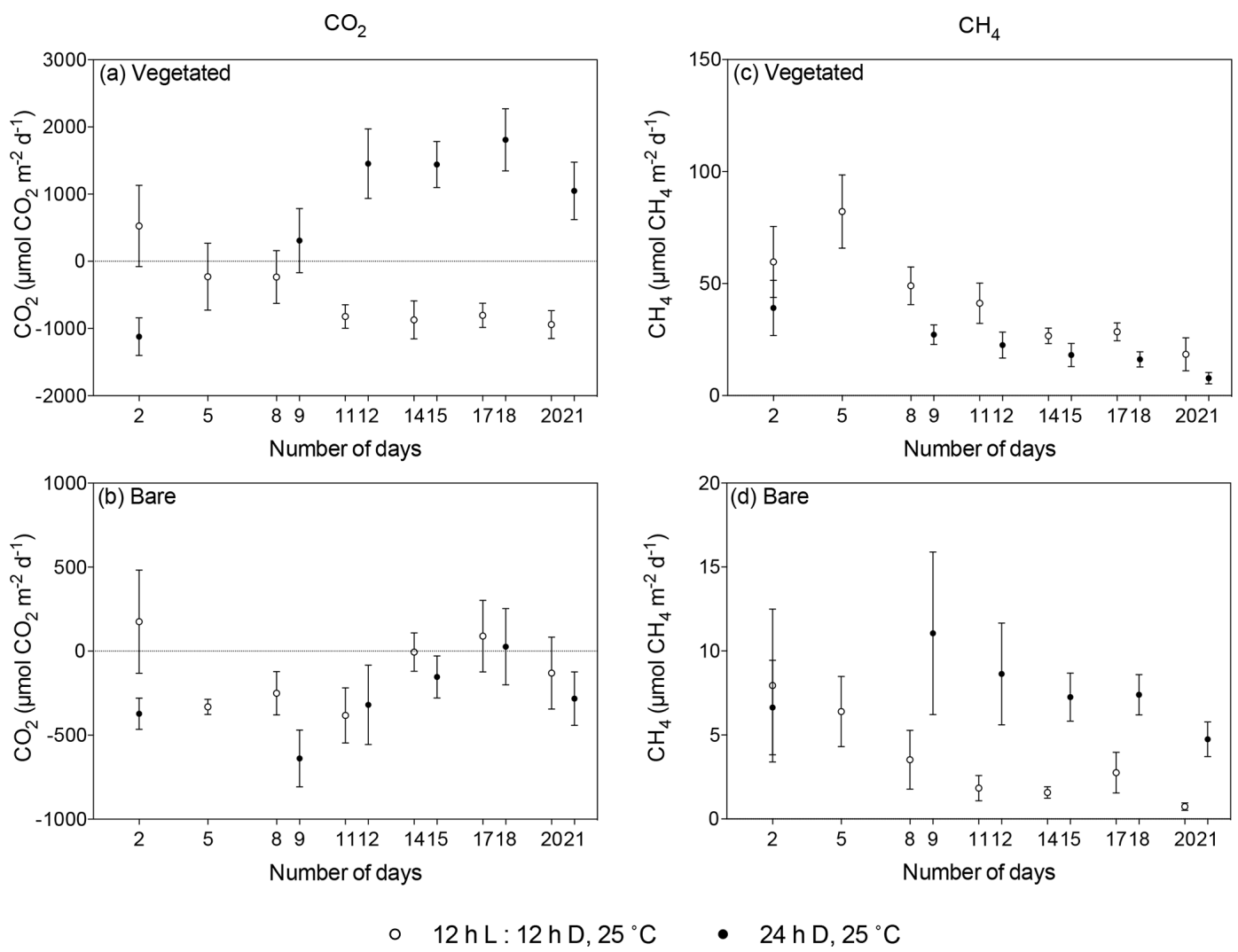

$12 \mathrm{hL}: 12 \mathrm{hD}, 25^{\circ} \mathrm{C}$

- $24 \mathrm{hD}, 25^{\circ} \mathrm{C}$

Figure 5. Comparison of mean $\pm \mathrm{SE} \mathrm{CO}_{2}$ (left) and $\mathrm{CH}_{4}$ (right) fluxes in (a, c) vegetated and (b, d) bare sediments maintained at $25^{\circ} \mathrm{C}$ with a $12 \mathrm{~h} \mathrm{~L}: 12 \mathrm{~h} \mathrm{D}$ photoperiod (white) and communities kept at $25^{\circ} \mathrm{C}$ with a $24 \mathrm{hD}$ period (black) over the experimental period (number of days since the onset of the experiment). Dots indicate mean values, and error bars indicate standard error of the mean.

\section{Discussion}

\subsection{Carbon dioxide and methane air-seawater fluxes}

The values reported for $\mathrm{CO}_{2}$ and $\mathrm{CH}_{4}$ fluxes varied greatly between the two sites studied here, with higher fluxes in the more organic sediments with higher biomass density (S2). $\mathrm{CO}_{2}$ and $\mathrm{CH}_{4}$ fluxes were also highly variable over time at the studied site, as the first evaluation of fluxes at the same location delivered rates up to 100 -fold above the rates of the second measurement 1 week later. Hence, organic matter availability along with temperature may account for the large variation in $\mathrm{CO}_{2}$ and $\mathrm{CH}_{4}$ fluxes. Additionally, the variability of $\mathrm{CO}_{2}$ and $\mathrm{CH}_{4}$ fluxes could also be supported by infaunal species present in the cores that were not recorded in this study. These trends were similar to results reported in previous studies, as a high variability between species and lo- 

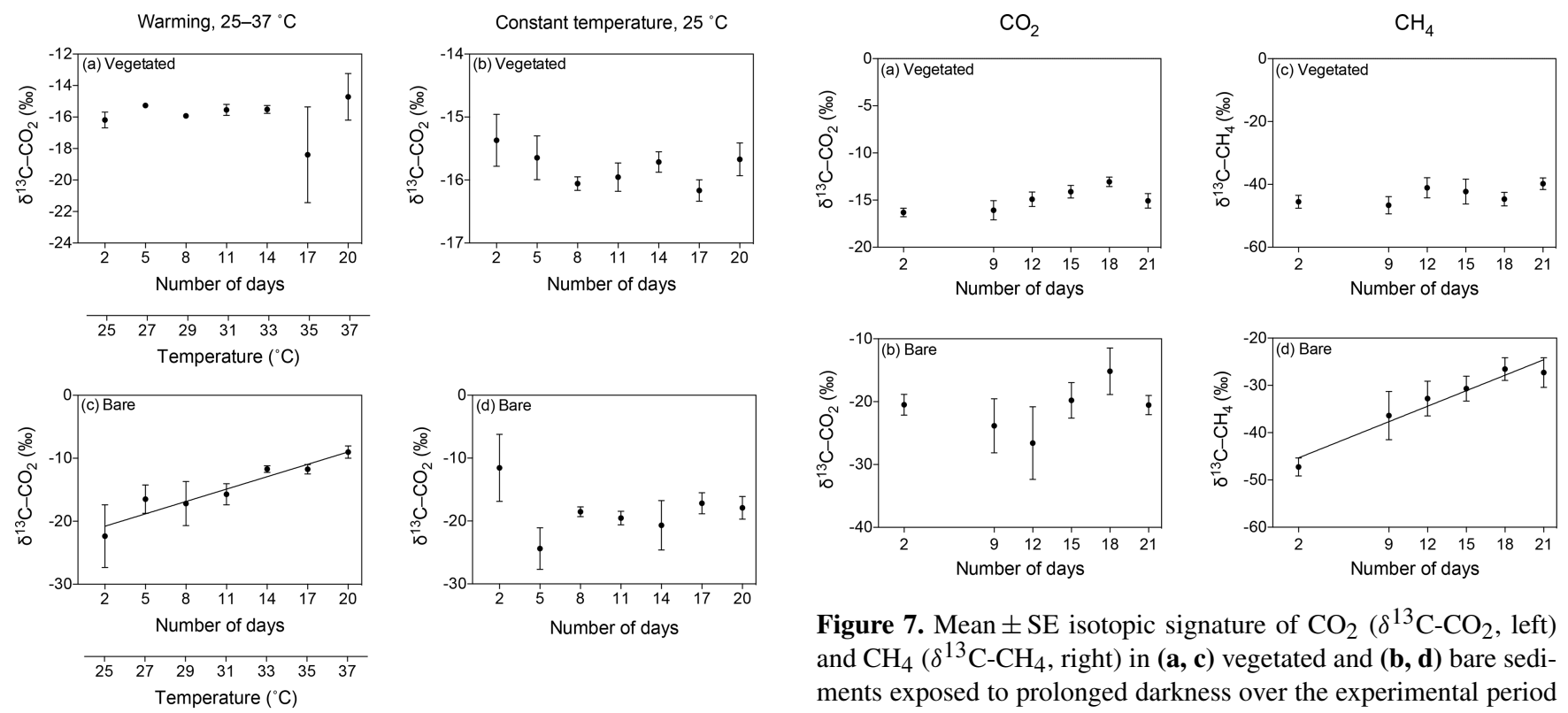

Figure 7. Mean $\pm \mathrm{SE}$ isotopic signature of $\mathrm{CO}_{2}\left(\delta^{13} \mathrm{C}-\mathrm{CO}_{2}\right.$, left $)$ and $\mathrm{CH}_{4}\left(\delta^{13} \mathrm{C}_{-}-\mathrm{CH}_{4}\right.$, right $)$ in $(\mathbf{a}, \mathbf{c})$ vegetated and $(\mathbf{b}, \mathbf{d})$ bare sediments exposed to prolonged darkness over the experimental period (number of days since the onset of the experiment).
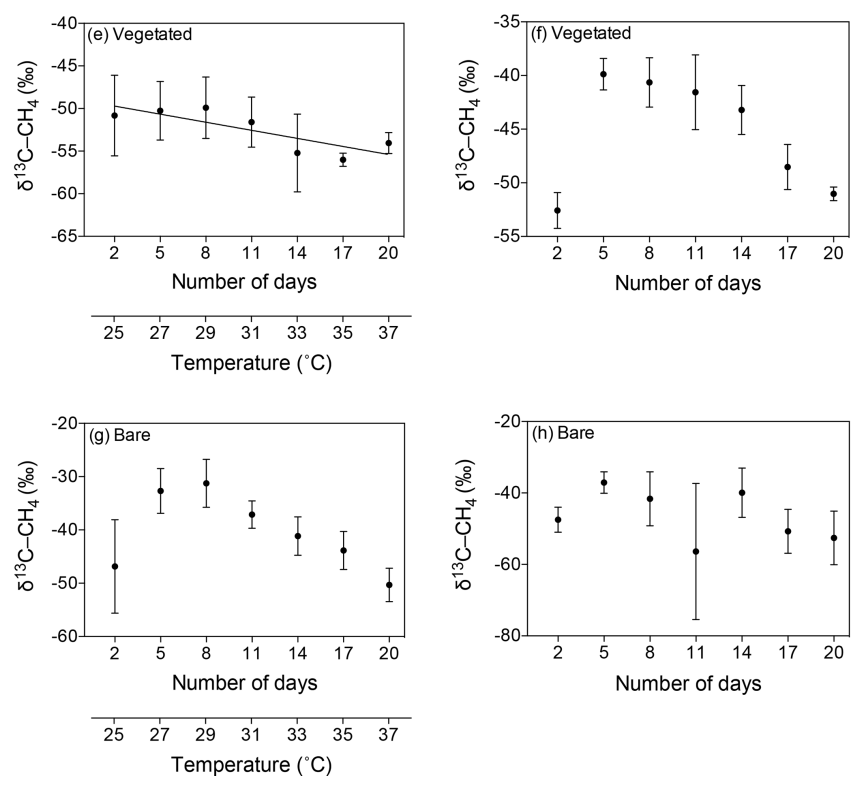

Figure 6. Mean $\pm \mathrm{SE}$ isotopic signature of $\mathrm{CO}_{2}\left(\delta^{13} \mathrm{C}-\mathrm{CO}_{2}\right)$ and $\mathrm{CH}_{4}\left(\delta^{13} \mathrm{C}-\mathrm{CH}_{4}\right)$ in the communities experiencing warming from 25 to $37^{\circ} \mathrm{C}$ (left) and the communities maintained at $25^{\circ} \mathrm{C}$

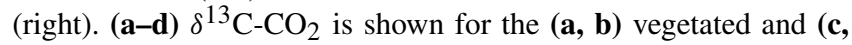
d) bare sediments over the experimental period (number of days since the onset of the experiment). (e-h) $\delta^{13} \mathrm{C}_{-}-\mathrm{CH}_{4}$ is shown for the $(\mathbf{e}, \mathbf{f})$ vegetated and $(\mathbf{g}, \mathbf{h})$ bare sediment over the experimental period. The second $x$ axis indicates the temperature increase for the community experiencing warming.

cations was found (cf. Table 1 in Garcias-Bonet and Duarte, 2017).

Even though there were some differences, carbon, nitrogen and phosphorus concentrations were generally similar, and they did not seem to have an effect on $\mathrm{CO}_{2}$ and $\mathrm{CH}_{4}$ fluxes. Carbon, nitrogen and phosphorus concentrations were 
est biomass, confirming our findings of higher fluxes at study site $\mathrm{S} 2$.

In terms of $\mathrm{CO}_{2}$ equivalents, only the bare sediment maintained at $25^{\circ} \mathrm{C}$ seemed to act as a $\mathrm{C}$ sink over the experimental period, while the vegetated sediments, both maintained at $25^{\circ} \mathrm{C}$ and exposed to warming, acted as sources of greenhouse gases. A sublethal disturbance, such as warming below the lethal threshold, can therefore lead to a shift of seagrass ecosystems from acting as net sinks to net sources of greenhouse gases, as demonstrated experimentally here.

\subsection{Effect of warming}

Both $\mathrm{CO}_{2}$ and $\mathrm{CH}_{4}$ fluxes were higher in vegetated compared to adjacent bare sediments, indicating elevated remineralization rates in vegetated sediments as well as a higher susceptibility of seagrass sediment to increasing temperatures. Vegetated sediments exposed to warming shifted from acting as a $\mathrm{CO}_{2}$ sink to an increasingly intense source, while the $\mathrm{CO}_{2}$ fluxes in vegetated sediments maintained at $25^{\circ} \mathrm{C}$ decreased over time. Warming leads to an increase in both community photosynthesis and respiration, with respiration's faster rate of increase (Harris et al., 2006) explaining the shift to a $\mathrm{CO}_{2}$ source in sediments exposed to a thermal stressor. However, the fluxes maintained at $25^{\circ} \mathrm{C}$ showed a net $\mathrm{CO}_{2}$ uptake with a mean of $464.78 \pm 156.6 \mu \mathrm{mol} \mathrm{CO}_{2} \mathrm{~m}^{-2} \mathrm{~d}^{-1}$ (Table S1), while those reported in a mixed Halodule sp. and Halophila sp. meadow in India showed a net $\mathrm{CO}_{2}$ release (dry season: $1190 \pm 1600 \mu \mathrm{mol} \mathrm{CO}_{2} \mathrm{~m}^{-2} \mathrm{~d}^{-1}$; wet season: $18400 \pm 8800 \mu \mathrm{mol} \mathrm{CO}_{2} \mathrm{~m}^{-2} \mathrm{~d}^{-1}$; Banerjee et al., 2018). Both values reported were measured at higher temperatures (dry season: $30 \pm 0.68^{\circ} \mathrm{C}$; wet season: $27.94 \pm 0.72{ }^{\circ} \mathrm{C}$; Banerjee et al., 2018) compared to our fluxes measured at $25^{\circ} \mathrm{C}$, also indicating that temperature might lead to higher fluxes. An initial high $\mathrm{CO}_{2}$ flux measured on day two after sampling could be an indicator for the experienced disturbance due to sample collection and transportation even though we allowed the cores some time to adapt.

Mean $\mathrm{CH}_{4}$ fluxes at in situ temperature $\left(25^{\circ} \mathrm{C}\right)$ in vegetated sediments were lower than the mean value of $85.1 \pm$ $27.8 \mu \mathrm{mol} \mathrm{CH}_{4} \mathrm{~m}^{-2} \mathrm{~d}^{-1}$ reported for other seagrass meadows in the Red Sea (Garcias-Bonet and Duarte, 2017). In contrast, the community exposed to warming reached a maximum average $\mathrm{CH}_{4}$ flux almost 4-fold higher than the community held at $25^{\circ} \mathrm{C}$ and showed a clear increase with warming relative to sediments held at $25^{\circ} \mathrm{C}$. The increase in $\mathrm{CH}_{4}$ fluxes with warming was consistent with reports from Barber and Carlson (1993) for a Thalassia testudinum community in Florida Bay and from Garcias-Bonet and Duarte (2017) for Red Sea seagrass communities, who reported higher $\mathrm{CH}_{4}$ fluxes at higher temperatures. Additionally, previous research has shown that methanogenesis has a higher thermal dependence than respiration and photosynthesis (YvonDurocher et al., 2014), confirming the trends seen here with increasing fluxes at higher temperatures. We also reported a 10-fold decline in $\mathrm{CH}_{4}$ fluxes over time for sediment communities maintained at $25^{\circ} \mathrm{C}$, which could be attributable to increased sulfate reduction, reduced $\mathrm{CH}_{4}$ production or a combination of both. Methane is produced under anoxic conditions in marine sediments, yet only a small portion is released, as $\mathrm{CH}_{4}$ production by methanogens is compensated for by $\mathrm{CH}_{4}$ oxidation by sulfate-reducing bacteria (Barnes and Goldberg, 1976). Similar to the trends seen in $\mathrm{CO}_{2}$ fluxes, the decrease in $\mathrm{CH}_{4}$ fluxes could be attributable to an initial stress response to the disturbance caused by sample collection and transportation. While reduced photosynthetic activity and a degradation in biomass could result in higher $\mathrm{CH}_{4}$ fluxes (Lyimo et al., 2018), the cores maintained at $25^{\circ} \mathrm{C}$ might show the effect of healthy conditions.

Increasing water temperature led to a decrease in the $\mathrm{CH}_{4} / \mathrm{CO}_{2}$ ratio. While there was $\sim 7 \%$ of sequestered carbon released as $\mathrm{CH}_{4}$ to the atmosphere in vegetated sediments at $25^{\circ} \mathrm{C}$ (on day two ), it decreased to $\sim 0.8 \%$ in vegetated sediments at $37^{\circ} \mathrm{C}$. In contrast, Banerjee et al. (2018) reported $\sim 1 \%$ of carbon being released as $\mathrm{CH}_{4}$.

The isotopic composition of $\mathrm{CO}_{2}$ in all treatments showed generally heavier isotopic signatures compared to previous reports of seagrass carbon (average $\delta^{13} \mathrm{C}$ value of $-7.73 \pm$ $0.11 \%$ ofor Red Sea seagrass and $-7.57 \pm 0.15 \%$ o for $H$. stipulacea in the Red Sea; Duarte et al., 2018), indicating various organic matter sources such as macroalgae blades $(13.38 \pm 0.3 \%$ o), mangrove leaves $(26.58 \pm 0.13 \%$ o $)$ and seston $(25.43 \pm 0.42 \%$; Duarte et al., 2018). However, the mean $\delta^{13} \mathrm{C}$ value of Red Sea seagrass sediments was reported to be $-13.36 \pm 0.4 \%$ (Garcias-Bonet et al., 2019a), similar to the results found in this study. Our chosen study sites were located in an enclosed lagoon with a high abundance of mangrove forests, leading to the conclusion that mangroves might be a major source of organic matter for our study sites. However, a recent study applying stable isotope mixing models found the major contributors to the organic matter in seagrass sediments in the Red Sea to be seagrass leaves and macroalgae blades, with contributions of $43 \%$ and $37 \%$, respectively (Garcias-Bonet et al., 2019a).

The isotopic signature of $\mathrm{CO}_{2}$ released from bare sediments shifted with warming, suggesting a shift from seston, mangroves and macroalgae to seagrass carbon as the source of $\mathrm{CO}_{2}$. In the vegetated cores, the isotopic composition of $\mathrm{CO}_{2}$ stayed rather constant, indicating several sources of organic carbon with no clear shift, regardless of warming.

The isotopic signature of $\mathrm{CH}_{4}$ in vegetated sediments confirmed its biogenic source as previous reports have shown that the isotopic signature of $\mathrm{CH}_{4}$ from biogenic sources can range from $-40 \%$ to $-80 \%$, while the isotopic signature of $\mathrm{CH}_{4}$ from geological and thermogenic sources ranges from $-30 \%$ to $-50 \%$ (Reeburgh, 2014). The isotopic composition of $\mathrm{CH}_{4}$ in bare sediments was generally at the lower end of this range, with no clear shift with increasing temperature.

The isotopic composition of $\mathrm{CH}_{4}$ can be determined by the production of $\mathrm{CH}_{4}$ (methanogenesis) leading to lower $\delta^{13} \mathrm{C}$ 
values and the oxidation of $\mathrm{CH}_{4}$ (methanotrophy) leading to higher $\delta^{13} \mathrm{C}$ values (Whiticar, 1990). Garcias-Bonet and Duarte (2017) reported fluctuations in the isotopic signature of $\mathrm{CH}_{4}$ in Red Sea seagrass meadows, suggesting an indication of both processes. With exposure to increasing temperatures, we observed a shift to a lighter isotopic signature of $\mathrm{CH}_{4}$ in vegetated sediments, thereby indicating an increasing $\mathrm{CH}_{4}$ production by methanogens with warming.

\subsection{Effect of prolonged darkness}

Communities maintained at $25^{\circ} \mathrm{C}$ with a $12 \mathrm{~h} \mathrm{~L}: 12 \mathrm{~h} \mathrm{D}$ photoperiod showed continuous net $\mathrm{CO}_{2}$ uptake, while the communities kept in the dark shifted, as expected, to a heterotrophic state, acting as a $\mathrm{CO}_{2}$ source. The net $\mathrm{CO}_{2}$ production corresponded to community respiration rates, while that with a $12 \mathrm{hL}: 12 \mathrm{hD}$ photoperiod corresponded to the net community production.

We found, however, no effect of prolonged darkness on $\mathrm{CH}_{4}$ fluxes, suggesting that the elevated $\mathrm{CH}_{4}$ fluxes in vegetated sediments were not directly supported by fresh photosynthetic products, but rather by the elevated organic matter content in vegetated sediments compared to bare ones. These findings were in contrast to those reported by Lyimo et al. (2018), who found increased $\mathrm{CH}_{4}$ fluxes under shading, indicating that degradation of belowground biomass might have been the key factor related to increased $\mathrm{CH}_{4}$ fluxes. However, they also reported varying results for different shading intensities, with low intensity having similar fluxes compared to their control group (Lyimo et al., 2018). In contrast, Öquist and Svensson (2002) found that photosynthesis might be regulating methane fluxes in a subarctic peatland ecosystem, with lower photosynthesis resulting in lower methane fluxes.

\subsection{Implications}

Reports on greenhouse gas fluxes by seagrass ecosystems are limited (Oremland, 1975; Barber and Carlson, 1993; Alongi et al., 2008; Deborde et al., 2010; Bahlmann et al., 2015; Garcias-Bonet and Duarte, 2017; Banerjee et al., 2018; Lyimo et al., 2018), and no reports had been previously published on how increasing seawater temperatures might affect greenhouse gas fluxes by seagrass ecosystems. Blue carbon ecosystems have been shown to turn into $\mathrm{C}$ sources when disturbances lead to mortality (Macreadie et al., 2015; Lovelock et al., 2017; Arias-Ortiz et al., 2018), consistent with the very large $\mathrm{CO}_{2}$ and $\mathrm{CH}_{4}$ fluxes observed in one vegetated sediment where the seagrass died when warmed to $33^{\circ} \mathrm{C}$. However, even where seagrass remained alive, warming led to elevated greenhouse fluxes. Additionally, the elevated nutrient and high organic matter stock in seagrass meadows, which supports 1.7 times more organic matter content than surrounding bare sediments, can promote an increase in $\mathrm{CO}_{2}$ and $\mathrm{CH}_{4}$ fluxes following disturbance (Gon- salves et al., 2011; Sotomayor et al., 1994). Our results suggest that this stock in seagrass sediments may be remineralized to support net greenhouse gas fluxes at the warmer temperatures reached and with further warming of the Red Sea. Hence, warming may, as other disturbances (Lovelock et al., 2017), shift seagrass ecosystems from net sinks to net sources of greenhouse gases, thereby providing a feedback mechanism that may contribute to further enhancing global warming.

\section{Conclusion}

In summary, this study reports, for the first time, experimental evidence that warming leads to increased greenhouse gas $\left(\mathrm{CO}_{2}\right.$ and $\left.\mathrm{CH}_{4}\right)$ fluxes in a $H$. stipulacea meadow in the Red $\mathrm{Sea}$, and it may lead to seagrass meadows shifting from acting as sinks to sources of greenhouse gases. Increased fluxes at higher temperatures can be an indication of higher remineralization rates and a higher susceptibility of vegetated sediments to temperature. The elevated organic matter content, higher biomass density and greater plant activity in vegetated sediments led to increased $\mathrm{CO}_{2}$ and $\mathrm{CH}_{4}$ fluxes in vegetated compared to bare sediments and a much steeper increase in $\mathrm{CO}_{2}$ and $\mathrm{CH}_{4}$ fluxes with warming. In addition, prolonged darkness led to an increase in $\mathrm{CO}_{2}$ fluxes, while $\mathrm{CH}_{4}$ fluxes decreased over time, also indicating organic matter to be the driver. However, we also found a high variability in fluxes over time, indicating that other factors, such as infaunal species, could play a role as well. While the current focus is on conserving blue carbon ecosystems from losses due to deteriorated water quality or mechanical damage, our results show that sublethal warming may also lead to emissions of greenhouse gases from seagrass meadows, contributing to a feedback between ocean warming and further climate change.

Data availability. All data are accessible in the repository Pangea (https://doi.org/10.1594/PANGAEA.905687, Burkholz et al., 2019b).

Supplement. The supplement related to this article is available online at: https://doi.org/10.5194/bg-17-1717-2020-supplement.

Author contributions. NGB, CMD and CB designed the project. $\mathrm{CB}$ collected the samples and conducted the experiments. NGB, $\mathrm{CMD}$ and $\mathrm{CB}$ analyzed the results; $\mathrm{CMD}$ and $\mathrm{CB}$ wrote the first draft of the manuscript; and all authors contributed substantially to the final draft. All authors approved the final submission. 
Competing interests. The authors declare that they have no conflict of interest.

Acknowledgements. We thank Paloma Carrillo de Albornoz, Mongi Ennasri and Vijayalaxmi Dasari for their help with analyses. We also thank Katherine Rowe and the Coastal and Marine Resources Core Lab (CMOR) for their assistance during field work and CMOR for their support with the experimental setup.

Financial support. This research has been supported by the King Abdullah University of Science and Technology through baseline and CARF funding (grant nos. FCC/1/1973-32-01 and BAS/1/1071-01-01).

Review statement. This paper was edited by Aninda Mazumdar and reviewed by two anonymous referees.

\section{References}

Alongi, D. M., Trott, L. A., Undu, M. C., and Tirendi, F.: Benthic microbial metabolism in seagrass meadows along a carbonate gradient in Sulawesi, Indonesia, Aquat. Microb. Ecol., 51, 141152, https://doi.org/10.3354/ame01191, 2008.

Arias-Ortiz, A., Serrano, O., Masqué, P., Lavery, P. S., Mueller, U., Kendrick, G. A., Rozaimi, M., Esteban, A., Fourqurean, J. W., Marbà, N., Mateo, M. A., Murray, K., Rule, M. J., and Duarte, C. M.: A marine heatwave drives massive losses from the world's largest seagrass carbon stocks, Nat. Clim. Change, 8, 338-344, https://doi.org/10.1038/s41558-018-0096-y, 2018.

Bahlmann, E., Weinberg, I., Lavrič, J. V., Eckhardt, T., Michaelis, W., Santos, R., and Seifert, R.: Tidal controls on trace gas dynamics in a seagrass meadow of the Ria Formosa lagoon (southern Portugal), Biogeosciences, 12, 1683-1696, https://doi.org/10.5194/bg-12-1683-2015, 2015.

Banerjee, K., Paneerselvam, A., Ramachandran, P., Ganguly, D., Singh, G., and Ramesh, R.: Seagrass and macrophyte mediated $\mathrm{CO}_{2}$ and $\mathrm{CH}_{4}$ dynamics in shallow coastal waters, PLoS One, 13, e0203922, https://doi.org/10.1371/journal.pone.0203922, 2018.

Barber, T. R. and Carlson, P. R. J.: Effects of seagrass die-off on benthic fluxes and porewater concentrations of $\mathrm{CO}_{2}, \mathrm{H}_{2} \mathrm{~S}$, and $\mathrm{CH}_{4}$ in Florida Bay sediments, in: Biogeochemistry of Global Change, edited by: Oremland, R. S., 530-550, Springer, Boston, MA, USA, 1993.

Barnes, R. O. and Goldberg, E. D.: Methane production and consumption in anoxic marine sediments, Geology, 4, 297-300, https://doi.org/10.1130/00917613(1976)4<297:MPACIA>2.0.CO;2, 1976.

Brown, J. H., Gillooly, J. F., Allen, A. P., Savage, V. M., and West, G. B.: Toward a metabolic theory of ecology, Ecology, 85, 17711789, https://doi.org/10.1890/03-9000, 2004.

Burkholz, C., Duarte, C. M., and Garcias-Bonet, N.: Thermal dependence of seagrass ecosystem metabolism in the Red Sea, Mar. Ecol.-Prog. Ser., 614, 79-90, https://doi.org/10.3354/meps12912, 2019a.
Burkholz, C., Garcias-Bonet, N., and Duarte, C. M.: Carbon dioxide and methane fluxes from Red Sea seagrass sediments, PANGAEA, https://doi.org/10.1594/PANGAEA.905687, 2019b.

Chaidez, V., Dreano, D., Agusti, S., Duarte, C. M., and Hoteit, I.: Decadal trends in Red Sea maximum surface temperature, Sci. Rep.-UK, 7, 8144, https://doi.org/10.1038/s41598-017-08146-z, 2017.

Dean, W. E. J.: Determination of carbonate and organic matter in calcareous sediments and sedimentary rocks by loss on ignition: comparison with other methods, J. Sediment. Petrol., 44, 242-248, https://doi.org/10.1306/74D729D2-2B2111D7-8648000102C1865D, 1974.

Deborde, J., Anschutz, P., Guérin, F., Poirier, D., Marty, D., Boucher, G., Thouzeau, G., Canton, M., and Abril, G.: Methane sources, sinks and fluxes in a temperate tidal Lagoon: The Arcachon lagoon (SW France), Estuar. Coast. Shelf S., 89, 256-266, https://doi.org/10.1016/j.ecss.2010.07.013, 2010.

Duarte, C. M.: Seagrass nutrient content, Mar. Ecol.-Prog. Ser., 67, 201-207, https://doi.org/10.3354/meps067201, 1990.

Duarte, C. M., Holmer, M., and Marbà, N.: Plant-microbe interactions in seagrass meadows, in: Interactions between macro- and microorganisms in marine sediments, edited by: Kristensen, E., Haese, R. R., and Kostka, J. E., 31-60, American Geophysical Union, Washington, D.C., 2005a.

Duarte, C. M., Middelburg, J. J., and Caraco, N.: Major role of marine vegetation on the oceanic carbon cycle, Biogeosciences, 2, 1-8, https://doi.org/10.5194/bg-2-1-2005, 2005b.

Duarte, C. M., Marbà, N., Gacia, E., Fourqurean, J. W., Beggins, J., Barrón, C., and Apostolaki, E. T.: Seagrass community metabolism: Assessing the carbon sink capacity of seagrass meadows, Global Biogeochem. Cy., 24, 1-9, https://doi.org/10.1029/2010GB003793, 2010.

Duarte, C. M., Agusti, S., and Regaudie-de-Gioux, A.: The role of marine biota in the biogeochemical and geological cycles of carbon, in: The role of marine biota in the functioning of the biosphere, edited by: Duarte, C. M., 39-54, Fundación BBVA, Madrid, 2011.

Duarte, C. M., Delgado-Huertas, A., Anton, A., Carrillo-deAlbornoz, P., López-Sandoval, D. C., Agustí, S., Almahasheer, H., Marbá, N., Hendriks, I. E., Krause-Jensen, D., and GarciasBonet, N.: Stable isotope $\left(\delta^{13} \mathrm{C}, \delta^{15} \mathrm{~N}, \delta^{18} \mathrm{O}, \delta \mathrm{D}\right)$ composition and nutrient concentration of Red Sea primary producers, Front. Mar. Sci., 5, 1-12, https://doi.org/10.3389/fmars.2018.00298, 2018.

Fourqurean, J. W., Duarte, C. M., Kennedy, H., Marbà, N., Holmer, M., Mateo, M. A., Apostolaki, E. T., Kendrick, G. A., KrauseJensen, D., McGlathery, K. J., and Serrano, O.: Seagrass ecosystems as a globally significant carbon stock, Nat. Geosci., 5, 505509, https://doi.org/10.1038/ngeo1477, 2012.

Garcias-Bonet, N. and Duarte, C. M.: Methane production by seagrass ecosystems in the Red Sea, Front. Mar. Sci., 4, 1-10, https://doi.org/10.3389/fmars.2017.00340, 2017.

Garcias-Bonet, N., Fusi, M., Ali, M., Shaw, D. R., Saikaly, P. E., Daffonchio, D., and Duarte, C. M.: High denitrification and anaerobic ammonium oxidation contributes to net nitrogen loss in a seagrass ecosystem in the central Red Sea, Biogeosciences, 15, 7333-7346, https://doi.org/10.5194/bg-15-7333-2018, 2018.

Garcias-Bonet, N., Delgado-Huertas, A., Carrillo-de-Albornoz, P., Anton, A., Almahasheer, H., Marbà, N., Hendriks, I. E., Krause- 
Jensen, D., and Duarte, C. M.: Carbon and nitrogen concentrations, stocks, and isotopic compositions in red sea seagrass and mangrove sediments, Front. Mar. Sci., 6, 1-12, https://doi.org/10.3389/fmars.2019.00267, 2019a.

Garcias-Bonet, N., Vaquer-Sunyer, R., Duarte, C. M., and Marbà, N.: Warming effect on nitrogen fixation in Mediterranean macrophyte sediments, Biogeosciences, 16, 167-175, https://doi.org/10.5194/bg-16-167-2019, 2019b.

Gonsalves, M. J., Fernandes, C. E. G., Fernandes, S. O., Kirchman, D. L., and Loka Bharathi, P. A.: Effects of composition of labile organic matter on biogenic production of methane in the coastal sediments of the Arabian Sea, Environ. Monit. Assess., 182, 385-395, https://doi.org/10.1007/s10661-011-1883-3, 2011.

Harris, L. A., Duarte, C. M., and Nixon, S. W.: Allometric laws and prediction in estuarine and coastal ecology, Estuar. Coast., 29, 340-344, https://doi.org/10.1007/BF02782002, 2006.

Hedges, J. I. and Stern, J. H.: Carbon and nitrogen determinations of carbonate-containing solids, Limnol. Oceanogr., 29, 657-663, https://doi.org/10.4319/lo.1984.29.3.0657, 1984.

Hoegh-Guldberg, O. and Bruno, J. F.: The impact of climate change on the world's marine ecosystems, Science, 328, 1523-1529, https://doi.org/10.1126/science.1189930, 2010.

IPCC: Climate Change 2014: Synthesis Report. Contribution of Working Groups I, II and III to the Fifth Assessment Report of the Intergovernmental Panel on Climate Change, edited by: Pachauri, R. K. and Meyer, L. A., p. 151, IPCC, Geneva, Switzerland, 2014.

Jayathilake, D. R. and Costello, M. J.: A modelled global distribution of the seagrass biome, Biol. Conserv., 226, 120-126, https://doi.org/10.1016/j.biocon.2018.07.009, 2018.

Kennedy, H., Beggins, J., Duarte, C. M., Fourqurean, J. W., Holmer, M., Marbá, N., and Middelburg, J. J.: Seagrass sediments as a global carbon sink: Isotopic constraints, Global Biogeochem. Cy., 24, 1-8, https://doi.org/10.1029/2010GB003848, 2010.

Lipkin, Y.: Halophila stipulacea, a review of a successful immigration, Aquat. Bot., 1, 203-215, https://doi.org/10.1016/03043770(75)90023-6, 1975.

Lovelock, C. E., Atwood, T., Baldock, J., Duarte, C. M., Hickey, S., Lavery, P. S., Masque, P., Macreadie, P. I., Ricart, A. M., Serrano, O., and Steven, A.: Assessing the risk of carbon dioxide emissions from blue carbon ecosystems, Front. Ecol. Environ., 15, 257-265, https://doi.org/10.1002/fee.1491, 2017.

Lyimo, L. D., Gullström, M., Lyimo, T. J., Deyanova, D., Dahl, M., Hamisi, M. I., and Björk, M.: Shading and simulated grazing increase the sulphide pool and methane emission in a tropical seagrass meadow, Mar. Pollut. Bull., 134, 89-93, https://doi.org/10.1016/j.marpolbul.2017.09.005, 2018.

Macreadie, P. I., Trevathan-Tackett, S. M., Skilbeck, C. G., Sanderman, J., Curlevski, N., Jacobsen, G., and Seymour, J. R.: Losses and recovery of organic carbon from a seagrass ecosystem following disturbance, P. R. Soc. B, 282, 1-6, https://doi.org/10.1098/rspb.2015.1537, 2015.

Myhre, G., Shindell, D., Bréon, F.-M., Collins, W., Fuglestvedt, J., Huang, J., Koch, D., Lamarque, J.-F., Lee, D., Mendoza, B., Nakajima, T., Robock, A., Stephens, G., Takemura, T., and Zhang, H.: Anthropogenic and Natural Radiative Forcing, in: Climate Change 2013: The Physical Science Basis. Contribution of Working Group I to the Fifth Assessment Report of the Inter- governmental Panel on Climate Change, edited by: Stocker, T. F., Qin, D., Plattner, G.-K., Tignor, M., Allen, S. K., Boschung, J., Nauels, A., Xia, Y., Bex, V., and Midgley, P. M., 659-740, Cambridge University Press, Cambridge, UK and New York, NY, USA, 2013.

Öquist, M. G. and Svensson, B. H.: Vascular plants as regulators of methane emissions from a subarctic mire ecosystem, J. Geophys. Res.-Atmos., 107, 1-10, https://doi.org/10.1029/2001JD001030, 2002.

Oremland, R. S.: Methane production in shallow-water, tropical marine sediments, Appl. Microbiol., 30, 602-608, 1975.

Por, F. D.: One hundred years of Suez Canal - A century of Lessepsian migration: retrospect and viewpoints, Syst. Zool., 20, 138159, https://doi.org/10.2307/2412054, 1971.

Qurban, M. A. B., Karuppasamy, M., Krishnakumar, P. K., GarciasBonet, N., and Duarte, C. M.: Seagrass distribution, composition and abundance along the Saudi Arabian coast of Red Sea, in: Oceanographic and biological aspects of the Red Sea, edited by: Rasul, N. and Stewart, I., 367-385, Springer, Cham., 2019.

Reeburgh, W. S.: Global Methane Biogeochemistry, in: Treatise On Geochemistry, edited by: Holland, H. D. and Turekian, K. K., 71-94, Elsevier, Oxford, 2014.

Regaudie-De-Gioux, A. and Duarte, C. M.: Temperature dependence of planktonic metabolism in the ocean, Global Biogeochem. Cy., 26, 1-10, https://doi.org/10.1029/2010GB003907, 2012.

Rhein, M., Rintoul, S. R., Aoki, S., Campos, E., Chambers, D., Feely, R. A., Gulev, S., Johnson, G. C., Josey, S. A., Kostianoy, A., Mauritzen, C., Roemmich, D., Talley, L. D., and Wang, F.: Observations: Ocean, in: Climate Change 2013: The Physical Science Basis. Contribution of Working Group I to the Fifth Assessment Report of the Intergovernmental Panel on Climate Change, edited by: Stocker, T. F., Qin, D., Plattner, G.-K., Tignor, M., Allen, S. K., and Bos, J., 255-315, Cambridge University Press, Cambridge, UK and New York, NY, USA, 2013.

Rosentreter, J. A., Maher, D. T., Erler, D. V., Murray, R. H., and Eyre, B. D.: Methane emissions partially offset "blue carbon" burial in mangroves, Sci. Adv., 4, eaao4985, https://doi.org/10.1126/sciadv.aao4985, 2018.

Ruiz, H. and Ballantine, D. L.: Occurrence of the seagrass Halophila stipulacea in the tropical West Atlantic, B. Mar. Sci., 75, 131-135, 2004.

Sea, M. A., Garcias-Bonet, N., Saderne, V., and Duarte, C. M.: Carbon dioxide and methane fluxes at the air-sea interface of Red Sea mangroves, Biogeosciences, 15, 5365-5375, https://doi.org/10.5194/bg-15-5365-2018, 2018.

Serrano, O., Almahasheer, H., Duarte, C. M., and Irigoien, X.: Carbon stocks and accumulation rates in Red Sea seagrass meadows, Sci. Rep.-UK, 8, 15037, https://doi.org/10.1038/s41598018-33182-8, 2018.

Soetaert, K., Petzoldt, T., Meysman, F., and Meire L.: marelac: Tools for Aquatic Sciences, R package, available at: https: //cran.r-project.org/web/packages/marelac/marelac.pdf (last access: 19 November 2018), 2016.

Sotomayor, D., Corredor, J. E., and Morell, J. M.: Methane flux from mangrove sediments along the Southwestern Coast of Puerto Rico, Coast. Estuar. Res. Fed., 17, 140-147, https://doi.org/10.2307/1352563, 1994. 
Unsworth, R. K., McKenzie, L. J., Collier, C. J., Cullen-Unsworth, L. C., Duarte, C. M., Eklöf, J. S., Jarvis, J. C., Jones, B. L., and Nordlund, L. M.: Global challenges for seagrass conservation, Ambio, 48, 801-815, https://doi.org/10.1007/s13280-018-1115y, 2019.

Whiticar, M. J.: A geochemial perspective of natural gas and atmospheric methane, Org. Geochem., 16, 531-547, https://doi.org/10.1016/0146-6380(90)90068-B, 1990.

Wiesenburg, D. A. and Guinasso, N. L. J.: Equilibrium solubilities of methane, carbon monoxide, and hydrogen in water and sea water, J. Chem. Eng. Data, 24, 356-360, https://doi.org/10.1021/je60083a006, 1979.
Wilson, S. T., Böttjer, D., Church, M. J., and Karl, D. M.: Comparative assessment of nitrogen fixation methodologies, conducted in the oligotrophic north pacific ocean, Appl. Environ. Microb., 78, 6516-6523, https://doi.org/10.1128/AEM.01146-12, 2012.

Yvon-Durocher, G., Allen, A. P., Bastviken, D., Conrad, R., Gudasz, C., St-Pierre, A., Thanh-Duc, N., and Del Giorgio, P. A.: Methane fluxes show consistent temperature dependence across microbial to ecosystem scales, Nature, 507, 488-491, https://doi.org/10.1038/nature13164, 2014. 